\title{
Sometimes you end up where you are
}

\section{A trip back home for Christmas. By Beth Cato}

$\mathbf{0}$ ne of Grandma's favourite sayings had been: "Sometimes you end up where you are." Her quirky sense of humour helped her endure the arduous decades she spent perfecting her time machine.

Now Liz had ended up in 1984, her ten-yearold daughter Sasha beside her.

They stood before the holiday window spectacle of Canford's Furniture Store. The room-sized window displays along Main Street featured extravagant scenes that attracted visitors from hundreds of miles around - and from decades in the future.

"This is so cool." Sasha crouched in front of the building's corner scene depicting an icy stream, snowy forested banks and animatronic deer and raccoons. "It even smells like Christmas here!"

Liz bit back a giddy laugh. She thought it stank of moisture and car exhaust, but she wouldn't naysay Sasha. There was something magical about standing before a scene she'd loved throughout her childhood Christmases - and one that Sasha couldn't experience in the present. Around 2000, this building would be converted into law offices, its windows exchanged for soulless walls.

Liz had decided to come to this particular date because she'd found it highlighted several times in Grandma's scientific journals, no explanations included.

"Look, Mom, that deer has squinty eyes like it's throwing up!" Sasha said with a giggle, pointing to a mechanical deer that bobbed its head over the stream.

"I think it's supposed to be drinking," said Liz. "Who are you?"

Liz turned around and gasped. There stood Grandma, alive, her shaggy hair black, streaked with silver. She shouldn't be in downtown tonight! They shouldn't be meeting at all!

Sasha stayed quiet as she shrank against Liz's hip; she'd been well-schooled in how to handle herself in the past.

“Oh, hi. We're here to see the displays.” Liz kept her voice casual.

Grandma advanced on her, blatantly curious. Christmas lights dappled her face. "Who are you?" she repeated. "You stand like a woman in my family."

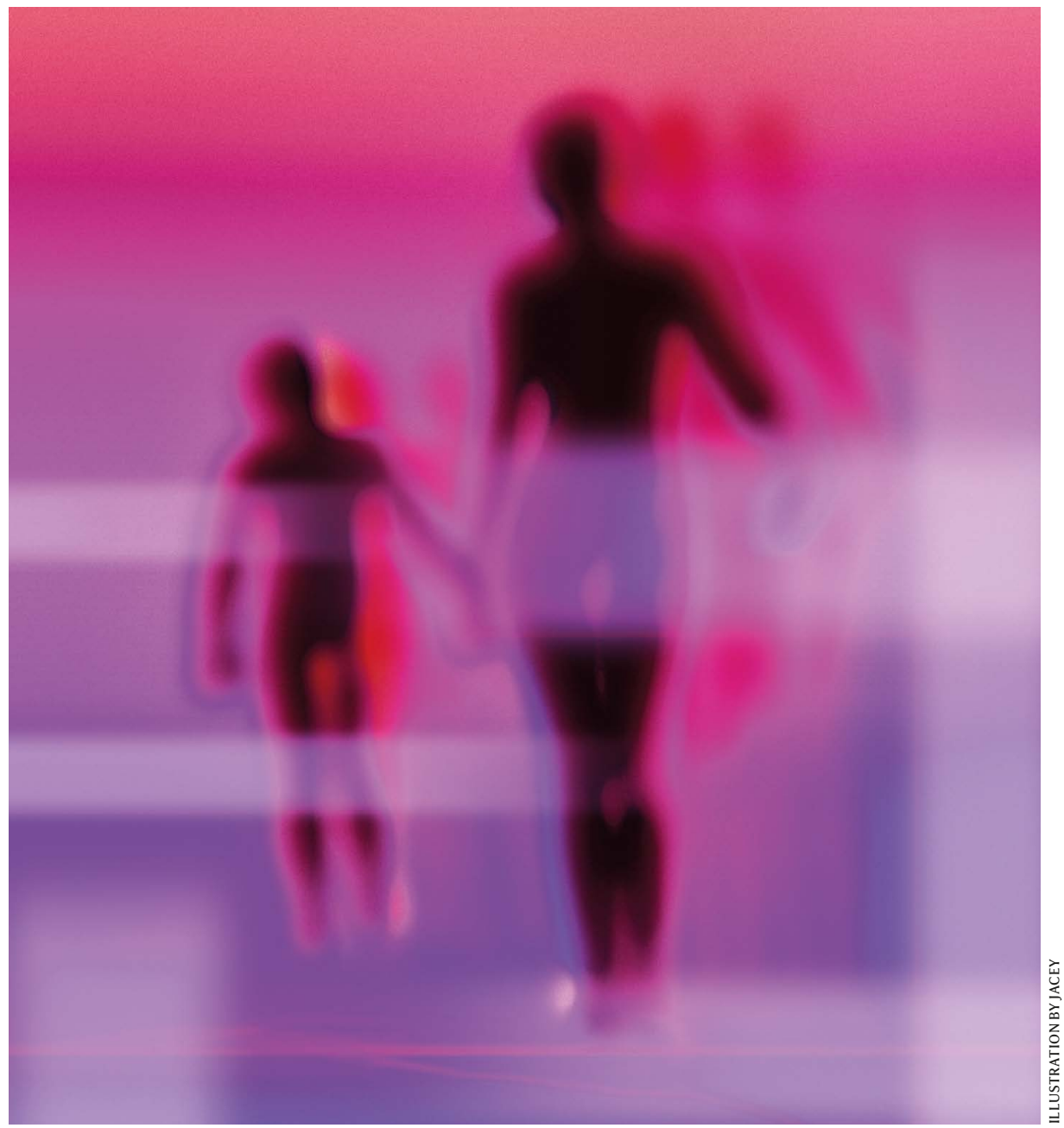

Liz had been so careful to acquire periodappropriate attire, to fix their hair just-so, but of course Grandma recognized the family stance.

Grandma frowned. “You can't - you look like my little Liz, but -"

Liz couldn't hold back any longer. "But Liz is four years old and should be tucked into bed by now, huh?"

Grandma inhaled sharply. "You are - you did - my machine, it works?" she whispered.

A car rumbled by, blaring a Bing Crosby tune. "Yes." The simple word created a small cloud in the crisp night air.

"And who are you?" Grandma asked, kneeling before Sasha.
Sasha looked to Liz for permission to speak. "I'm Sasha."

"My middle name." Grandma shook her head in awe as she stood. "I can't believe this."

"I'm sorry," Liz blurted out. “I didn't think you'd be anywhere near downtown tonight. I only came to this day because your journals -" She stopped. “Oh.”

"What did - what do I write?" Grandma asked.

“This date's mentioned several times like it's important. I guessed you made some big discovery today in your lab."

"Huh. I suppose I did make a discovery, but not there." Grandma smiled.

Liz thought back over her life. As a child, 


\section{Futures}

she'd loved following Grandma around in the lab - and Grandma had adored her company. While the rest of the family increasingly dismissed Grandma as a crackpot, Liz's faith had never wavered. Once she was done at university, she'd returned home to become caretaker of Grandma and her - at long last - functional time machine.

“Can I hug you?" Sasha asked.

“Oh sweetie." Grandma opened her arms to accept the girl, who promptly broke out in sobs. Grandma met Liz's eye. “I guess in your time I'm ...? No, don't answer. Of course I'd be ... gone. You look about 40 , after all. I'd be nearing 100."

"All I'll say is that Sasha misses you more than anything." And I miss you more than anything, Liz wanted to say, but could not give voice to her heartbreak.

“Good," Grandma said softly. “I'm glad I get to know her."

They stayed quiet as another family walked by, the children squealing with delight over the Santa's-workshop display.

“We can't ... we can't stay long," Liz said. "It takes months to charge up the machine and make the calculations, and we only get three hours maximum in a visit." She froze. "I shouldn't have said that much. You always told me to never meddle in the past -"

"I haven't told you yet, have I? So you're not in trouble. Come here, you." Sasha moved back, and Liz stepped into Grandma's embrace. Liz had become accustomed to Grandma's feebleness in her last years; her youthful strength came as a wonderful surprise.

“I miss you so much," Liz whispered. “I don't want you to be disappointed in me -"

"Where did you take the machine last?"

Liz blinked. "Back a century to birdwatch at the lake when it still existed. I wanted Sasha to see an impact of modern agriculture."

"Some of the birds are extinct now," Sasha added softly.
"And now you're both here. You're using my machine to learn. To help Sasha learn. I'm proud of you, Lizzy. I'm proud to know the woman you become."

Liz's eyes burned. "Sometimes you end up where you are,' right?”

Grandma squeezed her and stepped back. "Let's use our remaining time up right. Sasha, have you looked at Santa's workshop yet? He has a long scroll of names - let's see if you can find yours!"

“OK!"

Grandma and Sasha walked hand in hand to the next window. Liz dried her eyes and took in a deep breath of dankness and car exhaust. It smelt like Christmas.

Beth Cato resides in Arizona. She's the author of the Clockwork Dagger duology and the

Blood of Earth trilogy with Harper Voyager. Her website is BethCato.com. 